\title{
APPLICATION OF THERMOLUMINESCENCE (TL) TO CHARACTERIZATION OF PET FIBERS
}

\author{
By Keizo Miyasaka and Toshimasa Hashimoto \\ (Department of Textile and Polymeric Materials, Tokyo Institute \\ of Technology, Ookayama, Meguro-ku, Tokyo, 152)
}

\section{Introduction}

This note is prepared to show the usefulness of the thermoluminescence (TL) technique for the characterization of PET fibers. TL is the glow which a solid organic material irradiated at low temperature makes as it is heated. The secondary electrons extracted from the molecules by the irradiation ( $\mathrm{x}$-ray in this case), after having spent their kinetic energies, are trapped without recombining with their parents or any other positive ions in their vicinity. As the sample is heated, the trapped electrons are released to glow the luminescence at particular temperatures depending on the stability of the trapping sites. It is well known that TL is very sensitive to the relaxation behaviour of polymers. For example, Zlatkevich and Crabb $^{1)}$ recently studied the TL of Polyethylene (PE) specimens prepared by different ways to show that the TL glow curves were sensitive enough to distinguish each one from others. According to them, the TL was highly correlated with the NMR data obtained by Kitamaru and his coworkers ${ }^{2}$. The TL glow of PET has been studied by some researchers mainly with their interests concentrated into the identification of the glow peaks. For example, Ito and Nakakita ${ }^{3}$ measured simultaneously TL, TSC (Thermally stimulated Current) and dielectric loss, and attributed the low temperature TL peaks to three different relaxation mechanisms. It was natural that PET film specimens have been used in their $T L$ measurements instead of fiber specimens, because of the easy treatment and the expected high accuracy in the experiments.

In this note our interest is concentrated into a possibility of TL application to the characterization of PET fibers. We often meet a difficulty in distinguishing fibers with different properties by usual polymer characterization techniques such as $\mathrm{x}$-ray, birefringence, IR spectrum, density, etc. This means that some properties depend on the structure finer than that detected by these techniques. The high sensitivity of TL may make a useful method to characterize such a delicate structure.

\section{Experimentals}

Sample: Five kinds of PET fibers, provided by courtesy of Teijin Co. Ltd, were used after washing with acetone to remove the lubricant. As seen in Table 1, they were prepared under very different conditions; Sample 1,2 and 3 are as-spun fibers made at different spinning speeds, Sample 4 is a drawn fiber prepared by drawing Sample 1 under a usual conditions for commercial yarn making, and Sample 5 is a drawn fiber prepared under conditions particular to tire-yarn making and the molecular weight is larger than that of other four samples. X-ray diffraction photographs in Fig. 1 shows that the degree of crystalline orientation is high in all crystalline samples.

TL measurement: Each yarn was densely wound parallel on a sample holder of $\mathrm{Cu}$ plate, and set in a vacuum cryostat kept at a pressure of $10^{-3}$ Torr. Being cooled to $-180^{\circ} \mathrm{C}$ using liquid nitrogen, it was irradiated for 30 minutes by $x$-ray from a $\mathrm{Cu}$ tube on a Rigakudenki D3F apparatus under a condition of $30 \mathrm{KV}$ and $50 \mathrm{~mA}$. Thirty minutes after the irradiation, the sample was heated up to $250^{\circ} \mathrm{C}$ at a rate of $10^{\circ} \mathrm{C} / \mathrm{min}$. The glow was measured as a function of temperature with a 
Table 1 Sample characterization.

\begin{tabular}{lcccccc}
\hline No. & $\begin{array}{c}{[\eta]} \\
\text { at } 25^{\circ} \mathrm{C} \text { in OCP }\end{array}$ & $\begin{array}{c}\text { spinning speed } \\
\mathrm{m} / \mathrm{min} .\end{array}$ & drawing & [de/fil] & $\begin{array}{c}\text { density } \\
\mathrm{g} / \mathrm{cm}^{3}\end{array}$ & $\begin{array}{c}\text { birefringence } \\
\times 10^{3}\end{array}$ \\
\hline 1. UD & 0.60 & 1100 & undrawn & $195 / 24$ & 1.33 & 0.008 \\
2. POY & 0.60 & 3400 & undrawn & $75 / 24$ & 1.34 & 0.05 \\
3. USY & 0.60 & 6000 & undrawn & $75 / 24$ & 1.38 & 0.09 \\
4. FOY & 0.60 & 1100 & drawn & $75 / 24$ & $1.37_{5}$ & 0.15 \\
5. TY & 0.89 & - & drawn & $1000 / 250$ & $1.39_{5}$ & 0.19 \\
\hline
\end{tabular}

Naming: UD (Undrawn), POY (Partially Oriented Yarn), USY (Ultra-Speed Yarn), FOY (Fully Oriented Yarn), TY (Tire Cord Yarn)

$[\eta]$ is the value measured for fiber sample. These data were given by Teijin Co. together with samples. [de/fil] means the total denier and number of filaments in each yarn.

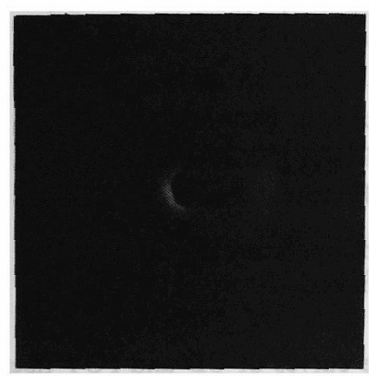

UD

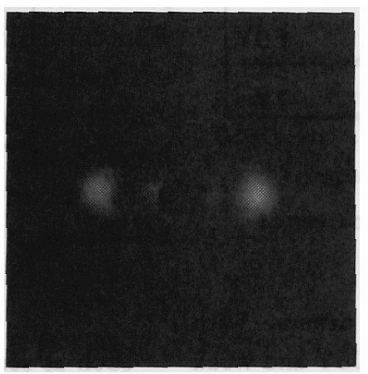

POY

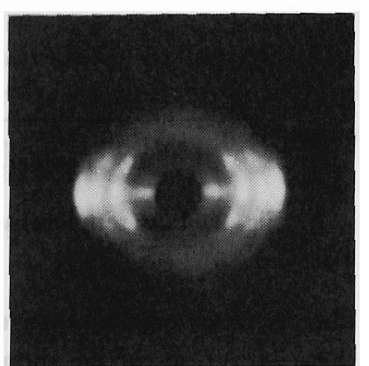

USY

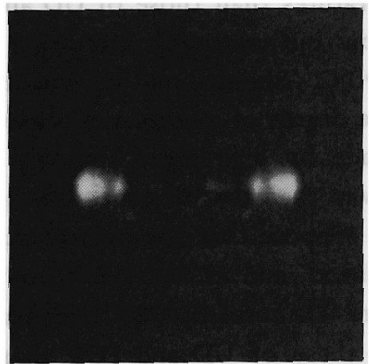

FOY

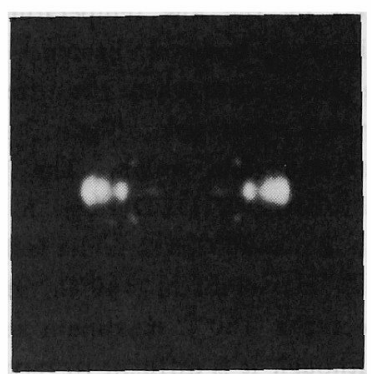

TY

Fig. 1 X-ray diffraction photographs of PET fibers used in this study. The naming of each sample should be referred to Table 1 .

photomultiplier (Hamamatsu TV R292). It should be remarked that the temperature control of fiber specimen was necessarily less accurate than that of film specimen. The dose of irradiation and the wave length distribution of $\mathrm{x}$-ray were not measured in this study.

Figure 2 shows the low temperature TL curves of PET fibers. The glow in the Figure is approximately from ca. $50 \mathrm{mg}$ of sample. Each glow curve has a similar broad peak around $-150^{\circ} \mathrm{C}$ which trails at higher temperature, as already reported by Ito et al. ${ }^{3)}$ for PET film. This results indicate that TL technique is applicable for the fibers as well as for the films. The asymmetric shape of the low temperature peak is attributed to three relaxation mechanisms, $\beta_{1}, \beta_{2}$ and $\beta_{3}{ }^{3)}$. A distinct shoulder is observed on the low temperature peak of USY fiber, which may be a specialty of the fibers prepared by high speed spinning. It is remarked that the low temperature glow of TY 


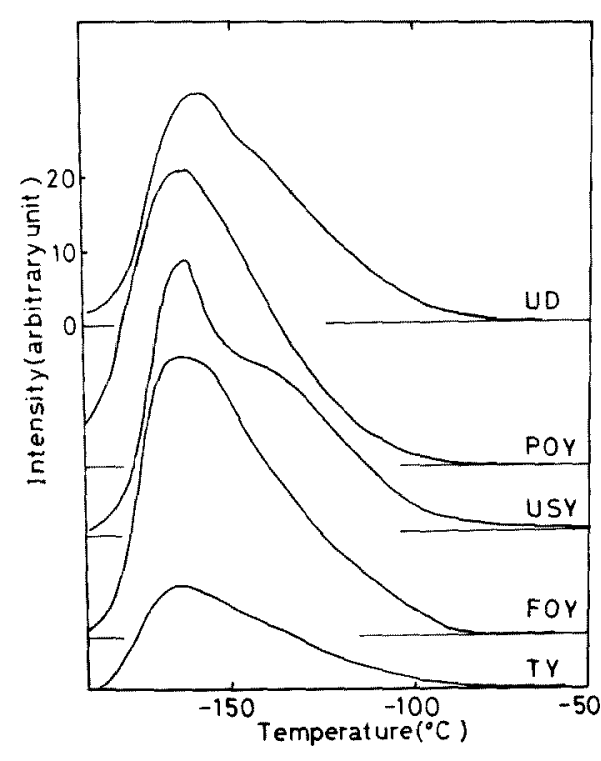

Fig. 2 Low temperature glow curves of PET fibers.

fiber is much smaller than these of others. With these exceptions of the shoulder of USY and weak glow of TY fibers, it is difficult to distinguish a fiber from others by the low temperature TL curves. The stituation, however, becomes quite different at high temperature where the difference of the glow curves is remarkable. Figure 3 shows the high temperature glow curves. The TL is characterized as follows; (1) UD fiber: it has a peak with a maximum at $90^{\circ} \mathrm{C}$, a shoulder at $120^{\circ} \mathrm{C}$ and a very weak maximum at $160^{\circ} \mathrm{C}$. It was possible to detect the $160^{\circ} \mathrm{C}$ maximum on the original chart, although it is difficult to recognize it in Fig. 3. The glow increases with increasing temperature above ca. $180^{\circ} \mathrm{C}$. The $90^{\circ} \mathrm{C}$ maximum may be attributed to the glass transition, (2) POY fiber: The TL curve is very similar to that of UD fiber, although the $170^{\circ} \mathrm{C}$ peak is more distinct than that of UD fiber. It is well known that the annealing effect on the fine structure of PET changes discontinuously at about $160^{\circ} \mathrm{C}^{4}$. This is related to the stepwise increase in the chain mobility within the crystal and also in the crystal boundaries at the temperature. The $160^{\circ}-170^{\circ} \mathrm{C}$ peak must be related to this characteristic temperature. (3) USY fiber: The TL curve has a maximum at $120^{\circ} \mathrm{C}$ without any other structure

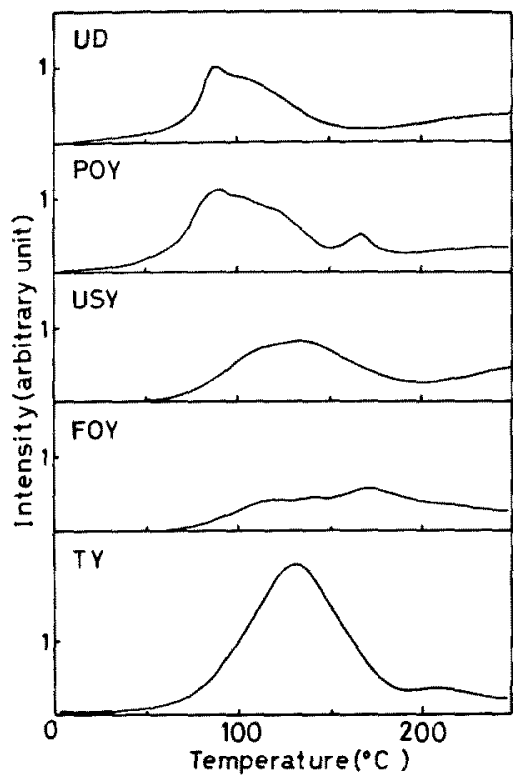

Fig. 3 High temperature glow curves of PET fibers.

such as seen on the curves of UD and POY fibers. As a whole, the glow curve shifts to higher temperatures than those of UD and POY fibers. The glow increases with increasing temperature above $200^{\circ} \mathrm{C}$. Shimizu and his coworkers ${ }^{5)}$ showed that the degree of amorphous orientation of PET fibers made by high speed spinning procedure is much lower than that of usual drawn fibers. This makes us suppose that the amorphous chains are highly relaxed, and as the results, that the high temperature TL curve of USY fiber may be similar rather to these of UD and POY than to these of FOY and TY fibers. The results shown in Fig. 3, however, indicate that the supposition is not probable. This may be due to the fact that the relaxation behavior of PET amorphous chains is much affected by coexisting crystalline phase ${ }^{6}$ ). (4) FOY fiber: The TL curve has a widely distributed peak with three weak maximums at $110^{\circ} \mathrm{C}, 140^{\circ} \mathrm{C}$ and $180^{\circ} \mathrm{C}$. The glow increases monotonously above $200^{\circ} \mathrm{C}$. Although the identification of these maxima is difficult, the flat shape of the TL curve indicates that the usual drawing causes a widely distributed state of aggregation of the amorphous chains. (5) TY fiber: The high temperature TL glow is very strong, whereas the low temperature glow was 
very weak as seen in Fig. 2. It is rather similar to that of USY, but is quite different from that of FOY prepared by after drawing as in the case of TY fiber. The anti-fatigue property seems to be correlated to the strong and comparatively sharp high temperature TL peak. This indicates a usefulness of TL technique in the characterization of the fatigue property of TY fibers. The similarity of TL peak of TY fiber to that of USY seems to support a widely believed idea that a soft structure is necessary for the anti-fatigue property of tire yarns.

\section{Conclusion}

The TL technique was applied to the PET fibers to show that the TL glow, particularly at high temperatures above $100^{\circ} \mathrm{C}$, could distinguish the PET fibers prepared under different conditions. The technique will be one of the most useful methods for the PET fiber characterization, when further systematic studies are made to clarify the correlation between the fine structure and the TL glow.

\section{Reference}

1) L. Y. Zlatkevich and N. T. Crabb, J. Polym. Sci., Phys, Ed., 19, 1177 (1981)

2) R. Kitamaru and F. Horii, Adv. Polym. Sci. 26, 137 (1978)

3) D. Ito and T. Nakakita, J. Appl. Phys., 51, $3273(1980)$

4) T. Matsumoto, K. Ehara, K. Ikegami, T. Kawai and H. Maeda, Sen-i Gakkaishi, 25, 5 (1969)

5) J. Shimizu, N. Okui and T. Kikutani, Sen-i Gakkaishi, 37, T-135 (1981)

6) I. Uematsu and T. Uematsu, Kobunshi-kagaku, $17,222(1960)$

Acknowledgement is made to Teijin Co. Ltd for his courtesy to provide sample fibers with some data for characterization, and to Dr. Mitsuishi of the company for his help.

\title{
TLのPET繊維の特徴づけへの応用
}

\author{
東京工業大学工学部宮坂啓象，橋本壽正 \\ 製造条件の異なる5種のPET緎維のTL在測定した結

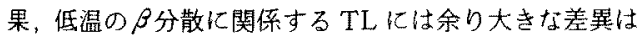 \\ みられなかったが，約 $100^{\circ} \mathrm{C}$ 以上の高温 TLには大さな \\ 差が睍われるととが加った。紡速 $1000 \mathrm{~m} / \mathrm{min}$ 程度の \\ 未延伸系, $3000 \mathrm{~m} / \mathrm{min}$ 程度の POY の未延伸糸は基本 \\ 的には三つの極大をもつ同形の高温 TLカーブを示す。

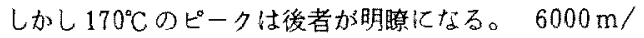 \\ ともに $1100 \mathrm{~m}, 3400 \mathrm{~m} / \mathrm{min}$ にみられたピークの構造が \\ 失なわれ帮一のピークになる。後延伸による延伸系の $\mathrm{T}$ \\ L注非常に平坦であったが，幾分構造が残され幾つかの \\ 極大がみられる。タイヤコード系は高温のTLの強度が \\ 強く，また形は $6000 \mathrm{~m} / \mathrm{min}$ の高速約系糸のそれに類似 \\ である。り上の結果，TLは（特に高温のTLはＰＥT䋐 \\ 維の特性化に有用であるととが示された。
} min の高速紡系系では，TLは全体として高温に移ると 